\title{
PEMANFAATAN INSTAGRAM DALAM PEMASARAN PRODUK USAHA KECIL MENENGAH KERIPIK TEMPE ALKHALIF PADA MASA PANDEMI COVID-19
}

\author{
Annisa Utami Wallad ${ }^{1}$, Nurlaila ${ }^{2}$ \\ Pendidikan Masyarakat Universitas Negeri Medan \\ annisawallad@gmail.com
}

\begin{abstract}
Abstrak
Penelitian ini bertujuan untuk menganalisis pemanfaatan instagram dalam pemasaran produk usaha kecil menengah Keripik Tempe Alkhalif Pada masa pandemi Covid-19. Metode yang digunakan dalam penelitian ini adalah penelitian kualitatif dengan pendekatan deskriptif. Informan dalam penelitian ini adalah pemilik UKM Keripik Tempe Alkhalif. Teknik pengumpulan data yang digunakan adalah teknik observasi, wawancara dan dokumentasi. Teknik yang digunakan dalam analisis data adalah pengumpulan data, reduksi data, penyajian data, dan penarikan kesimpulan. Triangulasi yang dilakukan untuk menjelaskan keabsahan data dengan menggunakan triangulasi sumber. Hasil penelitian menunjukkan bahwa pemanfaatan instagram dalam pemasaran produk usaha kecil menengah Keripik Tempe Alkhalif antara lain: (1) Penggunaan instagram oleh UKM Keripik Tempe Alkhalif dalam pemasaran produk melalui fitur-fitur instagram yaitu, Unggah foto dan video, Caption, komentar, Like, Instagram Stories, IGTV, Hasthagh, Dirrect Message; (2) Pemanfaatan instagram sebagai media pemasaran produk pada UKM Keripik Tempe Alkhalif memberikan manfaat dalam pengembangan usaha yaitu menjadi salah satu pendorong yang kuat bagi UKM untuk terus mengembangkan bisnisnya,; (3) Permasalahan yang terjadi dalam melakukan pemasaran produk Keripik Tempe Alkhalif melalui instagram, yaitu dalam hal pengelolaan media instagram yaitu slowrespon kepada pembeli dikarenakan pemilik sendiri yang mengelola instagram. Dan juga pembeli yang membandingkan harga dengan penjual lain; (4) Pendapatan UKM Keripik Tempe Alkhalif dalam pemasaran produk melalui instagram mengalami peningkatan penjualan hingga $40 \%$ dengan penjualan sebelumnya.
\end{abstract}

Kata Kunci: Pemanfaatan, instagram, pemasaran.

\begin{abstract}
This study aims to analyze the use of Instagram in the marketing of Alkhalif Tempe Chips small and medium business products during the Covid-19 pandemic. The method used in this research is a qualitative research with a descriptive approach. The informants in this study were the owners of Alkhalif Tempe Chips UKM. Data collection techniques used are observation, interview and documentation techniques. The techniques used in data analysis are data collection, data reduction, data presentation, and drawing conclusions. Triangulation is done to explain the validity of the data by using source triangulation. The results showed that the use of Instagram in product marketing for small and medium-sized businesses Alkhalif Tempe Chips included: (1) The use of Instagram by Alkhalif Tempe Chips SMEs in product marketing through Instagram features, namely, Upload photos and videos, Captions, comments, Likes, Instagram Stories, IGTV, Hasthagh, Direct Message; (2) The use of Instagram as a product marketing medium for Alkhalif Tempe Chips SMEs provides benefits in business development, namely being one of the strong drivers for SMEs to continue to develop their business; (3) The problems that occur in marketing Alkhalif Tempe Chips products through Instagram are in terms of managing Instagram media, namely the slow response of buyers because the owner himself manages Instagram. And also buyers who compare prices with other sellers; (4) The income of Alkhalif Tempe Chips UKM in marketing products through Instagram has increased sales by up to $40 \%$ with previous sales..
\end{abstract}

Keywords: Utilization, instagram, marketing. 


\section{PENDAHULUAN}

Pandemi Covid-19 memberikan dampak yang luar biasa terhadap berbagai sektor, khususnya sektor perekonomian, dimana keberadaan UKM yang perannya memberikan sumbangsih yang cukup besar terhadap laju perekonomian tidak lepas terdampak dari wabah Covid-19. Situasi krisis seperti ini tentu sangat berdampak kepada berbagai sektor ekonomi, salah satunya keberadaan Usaha Kecil Menengah(UKM) yang sangat memerlukan perhatian khusus. Salah satu faktor yang menyebabkan pendistribusian barang UKM kurang meluas karena pengusaha belum melakukan pemasaran online.

Beberapa UKM sudah memasarkan produknya lewat media sosial, situs marketplace, dan lainnya. Akan tetapi dalam prakteknya masih kurang maksimal, sehingga hasil yang didapat pun kurang maksimal. Asosiasi Pengusaha Ritel Indonesia (Aprindo) memaparkan sejumlah kendala permasalahan yang selama ini dialami oleh produk-produk dari sektor UKM. Kendala yang terjadi biasanya karena kualitas mutu atau kuantitas produk yang tidak berkesinambungan serta tidak sesuai dengan apa yang diharapkan. Selain itu, distribusi dan logistik produk seperti keterlambatan pengiriman atau sama sekali tidak mengirimkan pada saat sudah diminati konsumen, maka ini juga menjadi kendala bagi pemasaran produk UKM.

Di masa pandemi Covid-19 ini juga berdampak pada penjualan UKM Keripik Tempe Alkhalif yang mengalami penurunan omset. Berdasarkan wawancara yang telah saya lakukan dengan Ibu SI selaku pemilik Keripik Tempe Alkhalif pada tanggal 23 Februari 2021, sebelum adanya Pandemi Covid- 19 penghasilan UKM Keripik Tempe Alkhalif mencapai Rp.15.000.000,00 dan dimasa pandemi Covid-19 penghasilan UKM Keripik Tempe Alkhalif menurun hingga Rp.6.000.000,00. Dan menyebabkan adanya pengurangan jumlah pegawai dikarenakan kurangnya penghasilan yang didapat, selain itu, adanya hambatan distribusi produk dari produsen ke konsumen dikarenakan efek kebijakan PSBB(Pembatasan Sosial Berskala Besar) di Lubuk Pakam.

Persaingan yang ketat dalam dunia bisnis, menuntut pemilik Keripik Tempe Alkhalif, untuk memasarkan produknya dengan strategi penawaran atau promosi yang menarik, sehingga produk yang dihasilkan dan dipasarkan memiliki nilai jual yang tinggi, serta mampu bersaing dalam bisnis di bidang yang sama. Oleh karena itu, UKM Keripik Tempe Alkhalif memanfaatkan media sosial khususnya instagram untuk memasarka produknya usahanya. Sebabdi masa pandemi Covid-19 ini orang-orang takut untuk berinteraksi dengan banyak orang secara langsung. Melalui aplikasi instagram pemilik UKM Keripik Tempe Alkhalif mempromosikan usahanya, dan untuk pengantaran orderan menggunakan ojek online yaitu Go-jek, Grab dan jasa kurir lainnya seperti JNE \& JNT.

Pemasaran merupakan salah satu kegiatan pokok yang dilakukan oleh suatu perusahaan untuk mencapai tujuannya mempertahankan kelangsungan hidup, perkembangan dan profitabilitas. Pemasaran juga merupakan factor penting dalam memnuhi kebutuhan konsumen. Oleh karena itu, apabila perusahaan ingin usahanya terus berkembang atau konsumen memiliki pemahaman yang baik tentang perusahaan maka kegiatan pemasaran akan dapat memuaskan konsumen.

Salah satu media pemasaran digital melalui komunikasi visual yang trend saat ini adalah aplikasi media sosial instagram. Dapat diketahui instagram adalah sebuah aplikasi gratis yang fungsi utamanya sebagai tempat untuk meng-upload foto-foto. Aplikasi ini dapat digunakan melalui alat gadget seperti smartphone. Setelah sukses menjadi aplikasi yang diminati banyak pengguna, instagram menjadi media sosial yang banyak sekali peluang untuk berbisnis bagi para penggunanya, bisa dimanfaatkan sebagai media komunikasi pemasaran, 
melalui share foto-foto produk penjual, dan memiliki banyak followers. Instagram memudahkan konsumen untuk melihat produk yang dijual dan dapat langsung memberi komentar di bawah foto yang diminati.

Bahkan dalam sebuah studi yang dilakukan oleh Simply Measured,terungkap bahwa 54\% perusahaan dengan brand ternama dunia kini menggunakan instagram. Pelaku bisnis yang membuat akun instagram untuk mempromosikan barang dagangan biasanya lebih mudah menawarkan produk kepada calon pembelinya, karena biasanya sasaran pertama pembelinya adalah orang yang dekat dengannya, dengan instagram online shop dapat memberitahukan kepada teman-teman di sekitarnya. Diawali melalui mulut ke mulut sambil menunjukkan akun online shop yang dimaksud. Dengan instagram tentunya semakin mudah penjualan produk, karena dapat menunjukkan foto barang dagangannya dengan jelas.

Karena tampilan instagram menjadikan foto- foto produk yang diunggahnya ke internet layaknya katalog barang. Secara tidak langsung proses promosi menggunakan instagram tersebut masuk dalam lingkup komunikasi pemasaran menjadikan kelebihan tersendiri saat masa gadget saat ini sudah dapat memasaran produk menggunakan instagram karena pengguna instagram sudah dapat dipastikan merupakan pengguna yang melek teknologi. Instagram merupakan media sosial yang sangat digandrungi oleh masyarakat. Instagram memiliki fitur-fitur yang menarik. Berbagai fitur menarik yang tersedia pada instagram, memberi kemudahan bagi para penggunanya, baik untuk sekedar berbagi terkait aktivitas sehari-hari kepada pengguna lainnya,membagikan informasi, dan juga untuk berbisnis.

Berkaitan tentang penggunaan instagram dalam hal berbisnis, instagram dapat memberi kemudahan bagi para pelaku bisnis untuk memasarkan dan mempromosikan produknya melalui internet. Media sosial instagram dapat memberi kemudahan kepada kedua belah pihak, baik produsen maupun konsumen. Dengan adanya media sosial instagram, para pelaku bisnis online yang dalam hal ini adalah produsen sebuah produk makanan, minuman, atau barang, dapat memanfaatkan media tersebut guna mempromosikan produk dagangannya, sehingga dapat menjangkau masyarakat luas. Begitu pula dengan konsumen, media sosial instagram dapat dimanfaatkan untuk mencari referensi suatu produk barang atau jasa yang diinginkannya. Pasar bisnis di Indonesia khususnya yang bergerak di bidang kuliner, saat ini juga tidak lepas dari pemanfaatan instagram. Berbagai produk makanan dan minuman, yang dipasarkan secara online, dikemas sedemikian rupa untuk menarik minat konsumen. Tingkat persaingan yang ketat dalam bisnis di bidang kuliner tersebut, menuntut para pelaku bisnis untuk menciptakan produk yang tidak hanya memiliki cita rasa yang lezat, akan tetapi juga ciri khas untuk mendapatkan perhatian konsumen (Sholihah, 2018: 6).

Dampak Covid-19 terhadap pelaku UKM juga dialami oleh Dari beberapa UKM yang saya kunjungi di Lubuk Pakam, UKM Keripik Tempe Alkhalif merupakan salah satu UKM yang berinovasi dengan memanfaatkan media sosial untuk memasarkan produknya khususnya melalui instagram. Dan tentunya terdapat perbedaan peningkatan penjualan antara UKM yang menggunakan media sosial dan yang tidak menggunakan media sosial. UKM Keripik Tempe Alkhalif menghadirkan produk dengan kemasannya yang memiliki ciri khas, serta berbagai varian rasa yang menarik.

Ciri khas dan varian yang rasa yang unik adalah salah satu modal kreatif untuk mengenalkan brand yang dimiliki oleh Keripik Tempe Alkhalif di tengah menjamurnya bisnis saat ini. Berdasarkan uraian masalah di atas, maka penulis tertarik untuk melakukan penelitian dengan judul: "Pemanfaatan instagram dalam pemasaran produk usaha kecil menengah Keripik Tempe Alkhalif pada masa pandemi Covid-19.” 


\section{KAJIAN TEORI}

Instagram merupakan salah satu aplikasi yang sangat populer di kalangan pengguna media sosial. Nama instagram diambil dari kata instan" menjadi "insta" dan "gram", dari kata "telegram. Karenanya, instagram merupakan gabungan dari kata telegram instan. Dengan menggunakan kata instagram dapat diartikan sebagai aplikasi untuk mengirimkan informasi secara cepat, yaitu berupa foto, dalam bentuk mengelola foto, mengedit foto, dan berbagi foto dengan jejaring sosial lainnya (Ghazali, 2016:8). Berbeda dengan media sosial lainnya, instagram memiliki keunikan yang membuat instagram berbeda dengan media sosial lainnya. Sejak kemunculannya pada tahun 2010 silam, instagram sering memperbarui fitur yang ada sehingga fiturnya lebih lengkap dan menarik (Atmoko, 2012:28). Adapun fitur-fitur yang tersedia di instagram adalah Unggah Foto dan Video, Caption, Komentar, Like, Instagram Stories, IGTV, Hastagh, Dirrect Message. Pemasaran merupakan proses sosial dan manajerial dimana individu dan kelompok mendapatkan kebutuhan dan keinginan mereka dengan menciptakan, menawarkan, dan menukarkan produk yang bernilai satu sama lain (Kotler,2000:19).

Strategi pemasaran merupakan strategi untuk melayani pasar atau segmen pasar yang dijadikan target oleh perusahaan. Strategi pemasaran adalah logika pemasaran yang digunakan oleh perusahaan dengan harapan agar unit bisnis dapat mencapai tujuan perusahaan (Kotler, 2000: 76). Bauran pemasaran merupakan seperangkat alat pemasaran yang digunakan perusahaan untuk terus-menerus mencapai tujuan pemasarannya di pasar sasaran (Kotler,2003:17). McCarthy (dalam Kotler,2003:17) mengklasifikasikan bauran pemasaran kedalam empat komponen yang dikenal sebagai 4P, yakni : product(produk), price(harga), place(tempat, termasuk juga distribusi), dan promotion (promosi). Pengertian UKM menurut Suhardjono (dalam Rafika;2010) mendefinisikan usaha kecil adalah kegiatan ekonomi rakyat yang berskala kecil, dan memenuhi kriteria kekayaan bersih atau hasil penjualan tahunan serta kepemilikan sebagaimana diatur dalam undang-undang. Klasifikasi UKM dalam perspektif perkembangannya dapat diklasifikasikan menjadi empat kelompok yaitu: Livelohood Activities, Micro Enterprise, Small Dynamic Enterprise, Fast Moving Enterprise. World Health Organization (WHO) menjelaskan bahwa Coronaviruses (Cov) adalah virus yang menginfeksi sistem pernapasan. Infeksi virus ini disebut Covid-19.

\section{METODE}

Jenis penelitian yang digunakan dalam penelitian ini adalah penelitian kualitatif dengan pendekatan deskriptif. Sesuai dengan permasalahan yang menjadi fokus dalam penelitian ini untuk mengetahui gambaran deskriptif mengenai pemanfaatan instagram dalam pemasaran produk UKM Keripik Tempe Alkhalif, maka peneliti menggunakan metode penelitian deskriptif kualitatif dan mendeskripsikan data yang peneliti peroleh sebagai hasil suatu penelitian.Teknik pengumpulan data dalam penelitian ini yaitu observasi, wawancara, dan studi dokumentasi. Teknik purposive sampling dipilih dalam menentukan partisipan penelitian. Teknik purposive sampling yaitu teknik penentuan sample dengan pertimbangan tertentu (Sugiyono, 2005). Penelitian ini dilakukan pada bulan Mei 2021, berlokasi di UKM Keripik Tempe Alkhalif.

\section{HASIL PENELITIAN DAN PEMBAHASAN}

\section{Pemanfaatan Instagram dalam Pemasaran Produk Usaha Kecil Menengah Keripik Tempe Alkhalif}

Berdasarkan hasil penelitian dapat disimpulkan bahwa pemanfaatan instagram dalam 
pemasaran produk memudahkan proses penjualan. Hal ini sejalan dengan sebuah studi yang dilakukan oleh Simply Mascured mengungkapkan bahwa sebanyak 54\% perusahaan dengan brand terkenal telah menggunakan instagram sebagai media promosi, hal ini merangsang perusahaan dan penyedia iklan berlomba-lomba memasarkan produk mereka ke instagram, para pelaku bisnis memilih untuk mempromosikan produk mereka dengan alasan kemudahan menawarkan produk mereka ke konsumen.

Pemasaran dengan menggunakan media instagram dapat meminimalisir biaya yang digunakan untuk promosi. Dengan jangkauan yang luas dapat menembus pasar yang luas pula, bukan hanya sekedar di daerah sendiri namun juga dapat menembus pasar nasional dan juga internasional. Selain jangkauan luas penggunaan media sosial juga bergerak dengan cepat, melihat penggunaan instagram pada saat ini yang sangat tinggi. Selain itu, pemanfaatan instagram dalam pemasaran produk dapat meningkatkan penjualan produk, komunikasi dengan konsumen, dan memperluas jaringan pasar. Pemanfaatan instagram untuk memasarkan produk bagi UKM Keripik Tempe Alkhalif memberikan pengaruh yang positif selain dapat menghemat biaya juga dapat memperluas pemasaran. Sehingga pendapatan penjualan semakin meningkat dari pemanfaatan pengunaan instagram.

\section{Penggunaan Instagram dalam Pemasaran Produk Usaha Kecil Menengah Keripik Tempe Alkhalif}

Menurut hasil temuan TNS(Taylor Nelson Sofres) sebuah perusahaan riset dan analisis dari Inggris. Masyarakat Indonesia senang menggunakan Instagram untuk mencari inspirasi, membagi pengalaman travelling, tren terbaru, dan komunitas mobile first juga telah mendorong hasil bisnis yang berdampak bagi besar maupun kecil di Indonesia. Berikut ada data menarik tentang Instagram di Indonesia:

- $\quad 97 \%$ pengguna selalu menuliskan komentar dan menandai teman-teman mereka di dalam komentar.

- $\quad 89 \%$ pengguna Instagram di tanah air berada dalam rentang umur 18 - 34 tahun. 63 persen diantaranya merupakan perempuan.

- $\quad 85 \%$ pengguna Instagram di Indonesia juga membagikan posting mereka ke media sosial lain.

- $\quad 45 \%$ pengguna di Indonesia mengaku kerap membeli barang-barang yang mereka temui di Instagram

Dari data tersebut dapat disimpulkan bahwa sebagian masyarakat Indonesia merupakan pengguna aktif internet terutama media instagram dan mayoritas penggunanya berada di kalangan remaja yang mempunyai pengaruh yang sangat besar terhadap penjualan di instagram. Dapat disimpulkan bahwa penggunaan instagram oleh UKM Keripik Tempe Alkhalif menggunakan fitur-fitur instagram yang dapat menarik perhatian pembeli.

\section{Permasalahan yang terjadi dalam Pemasaran Produk Usaha Kecil Menengah Keripik Tempe Alkhalif Melalui Instagram}

Permasalahan yang terjadi saat pemasaran produk Usaha Kecil Menengah Keripik Tempe Alkhalif yaitu, pengelolaan instagram oleh pemilik dan perbandingan harga dari konsumen dengan penjual lainnya. Kelemahan yang dimiliki oleh Usaha Kecil Menengah di Indonesia pada umumnya hampir sama antara satu perusahaan dengan perusahaan lainnya. Kelemahan yang paling pokok yang dialami adalah pada aspek manajemen pemasaran. Pembinaan perlu dilakukan untuk menumbuhkembangkan Usaha Kecil Menengah di Indonesia menjadi UKM yang sehat dan tangguh serta tumbuh menjadi usahayang besar (Suparyanto, 2016:70). Dalam pemasaran produk melalui instagram mengalami kendala slowrespon terhadap pembeli dikarenakan UKM Keripik Tempe Alkhalif belum memiliki admin dan pemilik sendiri 
yang mengelola instagram. Dan saat proses pemasaran produk ada kalanya pembeli membandingkan harga dengan penjual lain.

\section{Hasil Pendapatan dengan Pemanfaatan Instagram dalam Pemasaran Produk Usaha Kecil Menengah Keripik Tempe Alkhalif}

Pendapatan UKM Keripik Tempe Alkhalif setelah memanfaatkan instagram mengalami peningkatan hingga 40\% dengan penjualan sebelumnya. Hasil pendapatan sangat berhubungan dengan bauran pemasaran. Bauran pemasaran adalah kelompok kiat pemasaran yang digunakan untuk mencapai sasaran pemasarannya dalam sasaran. Bauran pemasaran terdiri dari 4P(Product, Price, Place, Promotion) (Kotler,2000:68).Pada umumnya, apabila dana bertambah untuk kegiatan marketing maka jumlah pendapatan meningkat, salah satu jalan untuk menarik dan meningkatkan volume penjualan adalah promosi. Setelah masyarakat mengenal, mengetahui produk yang dipromosikan, maka diharapkan mereka mau mencoba dan membelinya. Dengan demikian tujuan perusahaan untuk meningkatkan hasil pendapatan akan tercapai (Buchari,2002:157). Promosi sangat diperlukan untuk menarik perhatian pembeli, dengan sering promosi akan menaikkan hasil pendapatan khususnya mengadakan promosi melalui fitur-fitur instagram.

\section{SIMPULAN}

Penggunaan instagram oleh UKM Keripik Tempe Alkhalif dalam pemasaran produk melalui fitur-fitur instagram yaitu, Unggah foto dan video, Caption, komentar, Like, Instagram Stories, IGTV, Hasthagh, Dirrect Message. Pemanfaatan instagram sebagai media pemasaran produk pada UKM Keripik Tempe Alkhalif memberikan manfaat dalam pengembangan usaha yaitu menjadi salah satu pendorong yang kuat bagi UKM untuk terus mengembangkan bisnisnya, meningkatkan penjualan produk, melakukan komunikasi dengan konsumen, serta mengembangkan jaringan pasar yang lebih luas lagi. Permasalahan yang terjadi dalam melakukan pemasaran produk Keripik Tempe Alkhalif melalui instagram, yaitu dalam hal pengelolaan media instagram karena UKM Keripik Tempe Alkhalif yang saat ini belum memiliki admin untuk mengelola instagram mengalami kendala, yaitu slowrespon kepada pembeli dikarenakan pemilik sendiri yang mengelola instagram. Dan juga pembeli yang membandingkan harga dengan penjual lain. Pendapatan UKM Keripik Tempe Alkhalif dalam pemasaran produk melalui instagram mengalami peningkatan penjualan hingga $40 \%$ dengan penjualan yang sebelumnya 150 keripik perbulan meningkat hingga 200 keripik tempe perbulannya. Adapun rekomendasi dalam penelitian ini:

a. Bagi UKM Keripik Tempe Alkhalif, agar meningkatkan pengelolaan instagram dalam pemasaran produk untuk lebih fastrespon terhadap pembeli, dan meningkatkan kualitas produk agar lebih unggul dibandingkan penjual lainnya.

b. Bagi Masyarakat, agar ikut serta mendukung UKM Keripik Tempe Alkhalif dengan mengajak orang-orang untuk membeli produk yang dijual.

c. Bagi Peneliti Lain, agar dikembangkan lagi hasil penelitian ini terkait dengan pemamfaatan instagram dalam pemasaran produk, karena tentunya hasil penelitian ini masih jauh dari kata sempurna.

d. Bagi Pemerintahan, diharapkan membuat pelatihan-pelatihan pada UKM untuk meningkatkan produk UKM khususnya pada pemasaran produk. 


\section{DAFTAR PUSTAKA}

Anto, Dajan. 1986. Pengantar Metode Statistik, Jilid II. Jakarta: Rineka Cipta

Arikunto, S. 2010. Prosedur Penelitian Suatu Pendekatan Praktik. Jakarta: Rineka Cipta

Atmoko Dwi, Bambang. 2012. Instagram Handbook Tips Fotografi Ponsel. Jakarta: Media Kita Basrowi dan Suwandi. 2008. Memahami penelitian kualitatif. Jakarta: Rineka Cipta

Basu, Swastha. 2002. Manajemen Pemasaran. Edisi Kedua. Cetakan Kedelapan. Jakarta: Penerbit Liberty

Departement Perindustrian. 1993. Tentang Usaha Kecil dan Rumah Tangga

Diamond, Stephanie. 2015. The Visual Marketing Revolution.Jakarta: Serambi

Hakiki, Rizki. Dakwah Di Media Sosial (Etnografi Virtual Pada Fanpage Facebook KH. Abdullah Gymnastiar) (Jakarta: 2016)

Hanoatubun, Silpa. 2020. "Dampak Covid-19 terhadap perekonomian indonesia". Journal of edupsycouns. 2(1):147

Indriyatno. 2018. Media Sosial. Jakarta: sriberkreasi

Kotler, Amstrong. 2000. Prinsip-prinsip pemasaran,edisi keduabelas, Jilid I. Jakarta: Erlangga

Kotler, Philip. 2000. Manajemen Pemasaran. Edisi Milenium. Jakarta: PT. Indeks Kelompok Gramedia

Kotler, Philip. 2006. Manajemen Pemasaran. Jilid I. Jakarta: PT. Indeks Kelompok Gramedia

Kotler, Philip. 2002. Manajemen Pemasaran, Jilid 2. PT. Prenhallindo: Jakarta

Miliza Ghazali. 2016. Buat Duit Dengan Facebook dan Instagram : Panduan Menjana Pendapatan dengan Facebook dan Instagram. Malaysia: Publishing House

Moleong, Lexy J. 2007. Metode Penelitian Kualitatif. Bandung: Remaja Rosda Karya

Nazir,Moh. 2009. Metode Penelitian. Bogor: Ghalia Indonesia

Priambada, Swasta. 2015. Manfaat Penggunaan Media Sosial Pada Usaha Kecil Menengah(UKM). Journal Of Internet Banking and Commerce. 14(2): 1-16

Radiosunu. 2001. Manajemen Pemasaran : Analisis, Perencanaan, Implementasi, dan Kontrol Jakarta: PT. Prehallindo

Rahmana. 2012. Peranan teknologi informasi dalam peningkatan daya saing usaha kecil menengah. Jurnal Teknik Industri. 13(1): 14-21

Redono, Daru. 2013. Simple Promotion an Branding untuk Usaha Kecil Menengah. Malang: Universitas Brawijaya Press(UB Press)

Sangaji, Harun. 2018. Pemanfaatan Instagram dalam Meningkatkan Pemasaran Online (Studi Deskriptif Kualitatif pada Akun Instagram lavanilla_photography). Skripsi. Tidak Diterbitkan. Fakultas Ilmu Sosial dan Ilmu Politik. Universitas Islam Kalimantan Muhammad Arsyadal Banjari: Banjarmasin.

Sholihah, Afiffatus. 2018. Penggunaan Instagram Sebagai Media Promosi( Studi Deskriptif Kualitatif pada Produk Teh Thailand Pikameame di Yogyakarta). Skripsi. Tidak Diterbitkan. Fakultas Ilmu Sosial dan Humaniora.Universitas Islam Negeri Yogyakarta: Yogyakarta.

Sugiyono. 2015. Metode Penelitian Kombinasi (Mix Methods). Bandung: Alfabeta

Sugiyono. 2017. Metode Penelitian Kuantitatif, Kualitatif, dan R\&D. Bandung : Alfabeta, CV.

Supranto, J. 2000. Teknik Sampling untuk Survei dan Eksperimen. Jakarta: PT Rineka Cipta.

Tim Pusat Humas Kementerian Perdagangan RI. 2014. Panduan Optimalisasi Media Sosial untuk Kementerian Perdagangan RI. Jakarta: Pusat Hubungan Masyarakat

Undang-undang Republik Indonesia Nomor 6 Tahun 2018 Tentang Kekarantinaan Kesehatan

Undang-undang Republik Indonesia Nomor 9 Tahun 1995 tentang Usaha Kecil. 
Zarella, D. 2010. The Social Media Marketing Book. Jakarta: PT Serambi Ilmu Semesta Anggota IKAPI 